Dorota Dakowska, "Competitive Universities? The Impact of International and European Trends on Academic Institutions in the 'New Europe' », European Educational Research Journal, vol. 16, n 5, p. septembre 2017, p. 588-604.

http://journals.sagepub.com/doi/10.1177/1474904116688024

DOI: https://doi.org/10.1177/1474904116688024

\title{
Competitive Universities? The Impact of International and European Trends on Academic Institutions in the 'New Europe'
}

\begin{abstract}
This contribution examines the domestic reinterpretations of international and European recommendations in Central and Eastern European countries (CEEC). It asks under what conditions these institutional recommendations, but also global processes such as the university rankings, affect domestic public policies. The countries of Central and Eastern Europe, which have experienced a far-reaching reform process since 1989, have been particularly affected by new standards promoted at the European and international level. The article shows that the combined external and domestic pressures affect HEI in multiple and sometimes contradictory ways. Based on the Polish and Ukrainian cases, it reassesses the (party) political factor in the reorientation of HE reforms. It shows that Europeanization and internationalization are neither uniform nor linear processes. Ultimately, the announced diversification of HEI appears as a longer-term process whose outcome remains uncertain.
\end{abstract}

\section{Keywords}

Higher Education, reforms, Central and Eastern Europe, Europeanization, Poland, Ukraine

The countries of Central and Eastern Europe, which have experienced a far-reaching reform process since 1989, have been particularly affected by new standards of public sector modernization promoted by European and international organisations (IOs). The criteria of EU accession have reinforced these trends.

This contribution examines the domestic reinterpretations of international and European recommendations in Central and Eastern European countries (CEEC), with a particular focus on the Polish and Ukrainian Higher Education (HE) systems. ${ }^{1}$ I consider under what conditions these institutional recommendations, but also global processes such as university rankings, affect domestic HE policies and governance. Commenting on the academic profession in Central and Eastern Europe, Philip Altbach stated that 'there is no other world region where higher education is as much in turmoil' (2003: 389). More 
than a decade after he made this observation, the HE systems of CEEC have undergone extensive reforms linked to their integration into the Bologna Process (Dobbins \& Khachatryan, 2014). In the educational sector, the CEEC have been subjected to the assistance programmes of various international organisations, including ones with a mandate to monitor educational policies (UNESCO) and others that have progressively gained authority in this area (Council of Europe, OECD, World Bank). ${ }^{2}$

This article analyses the selective uses of Bologna Process principles, of recommendations of the European Commission and of the above-mentioned IOs in domestic policy-making. It will focus on issues relative to HE governance and structure, diversification of HEI and funding, but also on national qualification frameworks, as all these elements have been considered as important preconditions for quality improvement. In both the Polish and Ukrainian cases, the reform and modernization of higher education were considered as indispensable elements to improve the position of the domestic system on the global educational market. The idea according to which universities should be competitive acquires a double meaning. First, it refers to the global academic competition for students and academic rankings (Erkkilä, 2013). Secondly, it triggers pressure among domestic universities, which have to fight more fiercely to attract students (and fees) in a context of demographic decline and to gain a better position in the domestic academic categorization/rankings, which may be vital for their funding.

The article shows that combined external and domestic pressures affect higher education (HE) systems in multiple and sometimes contradictory ways. On the one hand, European processes such as the building of a European Higher Education Area provide opportunities to domestic reformers. On the other, the Polish and Ukrainian case studies remind us that the political configuration should be taken into account at the domestic level. Ultimately, the announced diversification of HEI appears as a longer-term process whose outcome remains uncertain. In sum, Europeanization and internationalisation are neither uniform nor linear processes.

Poland and Ukraine differ in their socio-political background. Both countries have followed different historical trajectories (as satellite or member of the Soviet Union) and their democratisation processes have varied in timing. Poland deliberately turned to the West after 1989 (ultimately joining NATO and the EU), whereas Ukraine's 
geopolitical situation has remained more complex. Since its independence in 1991, Ukraine has been marred by political instability with several governmental crises followed by a serious economic crisis in 2009. More dependent on the Russian market, Ukraine finally signed an Association Agreement with the EU in 2014, albeit at a very high political cost, as the Russian annexation of Crimea and the war in the separatist Eastern territories followed the Maïdan 'revolution' triggered by president Yanukovych's refusal to sign the Agreement. These differences notwithstanding, the Polish and Ukrainian cases exemplify the impact of external recommendations and of domestic political power relations in HE policymaking.

Despite their heterogeneous research and HE systems it is possible to identify three rough patterns that go some way towards explaining the potential receptiveness of CEEC to external advice (Dakowska \& Harmsen, 2015). First, they share a Communist past, with a high degree of centralisation, ideological structuration of higher education curricula and a Soviet-inspired distinction between research and teaching. Yet, these systems differed in many ways, for example regarding the access to HE. Some countries, like the Czech Republic (formerly Czechoslovakia) or Poland, were able to rely on their interwar democratic experience and their acquaintance with the Humboldtian model of research university autonomy (Dobbins, 2011).

The second pattern is the shared experience of post-Communist transformation, increasing these countries' receptiveness to foreign assistance and international recommendations. The 1990 s were a time of exposure to neo-liberal reforms applied to the economic sector but also to sectors such as education or health, leading to a farreaching privatisation of the public sector. A third development that affected countries in the region unequally is the process of EU accession. In this respect a distinction must be made between the countries which have completed the negotiation process and accessed the European Union and those which have stayed out of it. The timing of the Bologna Process launch (in 1999) explains why many policy-makers from the new EU member states tended to consider its successive recommendations as part of a more general EU package. The EU accession process - involving conditionality and the allocation of financial resources - has had a noticeable impact on HE policies.

This contribution argues that the transformation process supported by international and European organisations has affected HE institutions. I investigate how definitions of the 
university objectives promoted by international and European organisations in terms of 'competitiveness' and 'internationalisation' are used in domestic contexts. While this trend has been well documented in Western countries, in some countries of Central and Eastern Europe it has taken a distinct form due to the limited timespan of the implementation of reforms and the differential perceptions of Western academic models.

Instead of reducing complex HE reforms to a unilateral adaptation to an external constraint - in line with the literature on Europeanization and diffusion (Börzel, Risse, 2000) - I propose to apprehend the relations between the European institutions and national academic spaces in their reciprocity. I therefore follow a sociologicalconstructivist approach of the European political field (Georgakakis, 2012; Guiraudon \& Favel, 2011) as it interacts with domestic political arenas. A first added value of a European political sociology is to shed empirical light on actor configurations and power relations in the construction of public 'problems' (Mangenot \& Rowell, 2012). A second contribution of this approach is to seize the relationship between external and domestic actors in their dynamics, through the political uses of European recommendations (Woll \& Jacquot, 2012).

The article is structured as follows. In the first part, I discuss the relationship between internationalisation and Europeanization from a theoretical perspective. I propose an analytical framework that pays attention to the temporalities of HE reform and their domestic context. In the second part, I apply this framework to the Central and Eastern European countries and discuss the main policy responses to external recommendations in terms of diversification of HEI and regarding the issue of fees. In the third part, I shed light on domestic actor configurations and show how policy entrepreneurs used European but also other external models, based on the Polish and Ukrainian cases.

\section{Higher Education Internationalisation and Europeanization Revisited}

The term 'internationalisation', used in both academic and applied policy analysis, can be defined in various ways. In view of the 'resurgence of internationalisation', Altbach (2007) describes the 'international imperative' as 'growing international forces that are influencing higher education'. However, the question remains open as to how and by 
whom this 'imperative' is voiced, and in which conditions it materialises and leads to direct consequences. Jane Knight defines internationalisation as 'the process of integrating international, intercultural or global dimension into the purpose, functions or delivery of post-secondary education' (Knight, 2003: 2). She notes the polysemy of the term, which may relate to international practices (mobility, partnerships, research programmes), the integration of an intercultural or global dimension into curricula, or the commercial trade of HE services (Knight, 2011). The author suggests adopting a combined bottom-up and top-down perspective to analyse the processes which take place at the national and institutional level. While top-down implementation studies focus on 'refractions, failures or deficits in policy implementation', 'bottom-up studies recognize the inevitability of mediations by professionals' (Rizvi \& Lingard, 2009: 53). Combining both approaches may be useful to shed light on the mechanisms of globalisation of Europeanization without taking them for granted (Dale, 1999). A political sociology approach provides a useful way to seize both the top-down and bottom-up dimensions of $\mathrm{HE}$ reform through the domestic uses of external recommendations.

\section{The European factor under debate}

In the past decade, academic debates have largely focused on the relative importance of the European Commission vs. governmental representatives in HE coordination at the European level. Some authors have presented the Bologna process as an example of 'resisting the EU' (Muller \& Ravinet, 2008). Critical scholars have for their part drawn attention to the structuring role played by EU institutions and processes such as the Lisbon strategy in promoting a market-based logic in various public sectors including higher education (Bruno, Clément, Laval, 2010; Garcia, 2007). A number of authors tend to agree that European educational initiatives constitute an 'EU policy' (Walkenhorst, 2008) increasingly dominated by the Commission (Croché, 2010; Keeling, 2006; Serrano-Velarde, 2015) and structured by the 'open method of coordination' (OMC) (Normand, 2010). My own research shows that the Commission has been a vital player of European HE policy coordination since it became a member of the Bologna Follow-Up Group (BFUG) Board in 2003. Due among other things to the EU programmes and funds earmarked for $\mathrm{HE}$, it is difficult to consider the Bologna 
Process and other exclusively EU initiatives as entirely distinct. Although the Bologna process has been 'presented as an intergovernmental process', 'supranational agencies played an important role in the preparations for the meeting in Bologna' whereas 'the European Commission has developed its own higher education strategy, building upon the Lisbon process but skilfully bringing on board elements of the Bologna Process' (Huisman \& al., 2012, p. 84).

'The Commission supports most of the Bologna Action lines, e.g. through initiatives ranging from the European Credit Transfer and Accumulation System (ECTS) label (promoting transparency of qualifications) to the 'Erasmus Mundus' Programme (fostering the attractiveness of European higher education on a global scale). These measures, which are part of the overall EU approach to educational matters, and the geographically wider - Bologna process reinforce each other, improving the chances of the genuine implementation of declared objectives across the various higher education systems. Such synergies are illustrated, for instance, by the impact of EU mobility actions on the call for more transparency and recognition of qualifications in Europe. The latter, in its turn, supports the EU's broader reform agenda under the Lisbon strategy. ${ }^{3}$

Clearly, the 'power of the purse' of the European Commission (Batory \& Lindstrom, 2011) makes a difference in HE templates and reforms in the CEEC, where the EU funds were an especially welcomed resource in a context of shrinking public funding. Beyond this EU-centred debate, the international dimension of the Bologna Process and of the European HE reform agenda is manifold. Policies coordinated at the European level have deeply influenced HE systems on the European continent and elsewhere. The process is based on the idea of tertiary education harmonisation and thus on a transnational comparison of HE systems, which entails the principle of competition.

While acknowledging the increasingly competitive orientation of the HE international market, many experts from CEEC consider that their country should fully participate in the Bologna Process to earn a better position in this field. ${ }^{4}$ Still, it is difficult to isolate the effects of the Bologna Process, which has built on circulating trends and instruments promoted by international and supranational organisations such as the Council of Europe, UNESCO and the European Commission, including diploma recognition, student and staff mobility facilitated by a credit transfer system, as well as quality 
assurance, to name just a few (Jorge de Melo 2013). This relationship between European and international factors of change requires further research.

\section{The complex impact of international incentives}

Regarding the international dimension of HE reforms, several authors have pointed out the need to consider the education system within a broader international context (Dale \& Robertson, 2009; Rizvi \& Lingard, 2009; Zgaga \& al., 2013). Scholars have heralded the emergence of a 'global educational policy field', in which the extent of the autonomy of public policies implemented at domestic level depends on the "strength of specific national capitals' (Lingard, 2006: 288). In the case of CEEC and their situation on the margins of the European Union, we may ask whether their relatively weak resources - compared with Western European countries - make them more dependent on international pressures.

While internationalisation seems to be an all-encompassing term, its academic definitions and considerations vary. Altbach (2007) describes the Bologna HE harmonisation approach as a regional version of the globalisation process (re)discovered in the 1990s. He acknowledges the power of the Western model as the American university 'so influential worldwide, constitutes an amalgam of international influences' (Altbach, 2007, 25). Influential global players in the field such as the World Bank and the World Trade Organization fuel the economic dimension of HE transformation. Thus HE internationalisation mirrors the inequalities linked to the economic globalisation process, such as the domination of dependent peripheries by Northern academic production centres (Altbach, 2007). According to Rizvi and Lingard (2009, p. x), 'globalization cannot be viewed as a generalised phenomenon, but rather needs to be seen as a dynamic phenomenon expressed in particular histories and political configurations'. This approach is useful to avoid reifying globalisation and to analyse the mechanisms and agency of this process, which may be understood through its practice, ideology and social imaginary (Rizvi \& Lingard, 2009).

While some authors trace back the increased activity of international organisations in education policy-making to the early 1990s and consider them as 'new arenas of education governance' (Leuze \& al., 2007), others suggest a more refined historical perspective. According to Karen Mundy (2007), educational multilateralism developed 
in the aftermath of the Second Word War, in several phases: firstly, 'embedded liberalism' marked by Keynesian policies and the promotion of the right to education by UNESCO in the Cold War context; secondly, starting in the 1960s, the growing role of the OECD, its Development Assistance Committee, but also its Annual Review of member countries' educational performance; thirdly, neoliberal policies calling for privatisation and the limitation of state intervention in which the World Bank has taken the lead, followed by the OECD, the EU and the World Trade Organisation (WTO) with its General Agreement on Trade and Services (GATS) negotiations (Mundy, 2007).

\section{Bridging the European / international divide}

A way to bridge the gap between explanations in terms of globalisation or Europeanization is to recognise that there is no obvious divide between both notions. For some authors, the European Union is just one among other international organisations involved in 'educational multilateralism' (Leuze \& al., 2007; Mundy, 2007). Still, the autonomisation of policies promoted at the European level has to be acknowledged. On the one hand, EU policy-makers re-appropriate pre-existing references and give them a distinct regional meaning, as was the case with the European Qualification Framework. On the other hand, EU policies have a scope and binding power that other international organisations do not enjoy.

Another manner of refining the Europeanization perspective is to examine alternative explanations of change, such as the inspiration drawn from models outside the European Union or references to narratives of global competition promoted by international organisations (Martens \& Wolf, 2009; Martens \& Jakobi, 2010). Furthermore, a way to escape a narrow perception of Europeanization as the mere uploading/ downloading of policy templates and to refine the Europeanization / internationalization relationship is to take into account the transnational channels of circulation of policy ideas. Government agencies such as the British Council or private organisations such as the Soros Foundation were active in promoting HE reforms focusing on transparency, accountability and quality assurance in the EU neighbourhood. The German Rectors' Conference (HRK) and the German Academic Exchange Service (DAAD) have been active in this field and have promoted the Bologna process in the European candidate and neighbourhood countries. ${ }^{5}$ 
Finally, although the external dimension of policy transformations can hardly be denied, it should not be taken for granted. The CEEC case reminds us that a policy transfer (emulation, inspiration, etc.) can be 'uninformed', 'incomplete' or 'inappropriate', according to the literature on policy diffusion terminology (Dolowitz, Marsh, 2000). Existing scholarship on the HE reforms in the region tells us that domestic political fields and actors are main sites of policy translation; it is not only difficult to isolate European models from other external (UK or US) inspirations but also to disentangle perceptions of appropriateness from strategic uses of these external models (Vukasovic 2012; 2015).

\section{Unpacking the External Dimension: the Central-Eastern European Perspective}

The transformations of higher education (HE) systems in Central and Eastern Europe (CEE) are a case in which international dynamics can hardly be disentangled from the European agenda. Thus it would be difficult to analyse internationalisation dynamics in the region without taking into account the way in which the prevailing European schemes have shaped academic programs, teaching methods, mobility, evaluation practices and governance.

In the case of the CEEC, European policies have played a major role over the last decades. First of all, the Bologna Declaration was not a Stunde Null of HE transformations in the region as it capped a whole decade of HE reforms in the aftermath of 1989 (Cîrstocea \& al., 2014). The 1990s were the heyday of international assistance to the CEEC. Hence, in the first reform stage, external references and sources of inspiration interfered and varied depending on national situations. International organisations such as the World Bank and the OECD were active in the field, providing funds, loans and expertise to the educational sector. The domestic reform strategies fuelled an internationalisation process of HE institutions, which could also be called Westernisation, as the outside references lay usually within the Western space and especially Anglo-American countries (Dakowska 2015, Vukasovic, 2015). However, the early 1990s were also a peak period for the European Commission, which emerged 
as a leader in the coordination of Western assistance to the transition countries, in particular through its Poland and Hungary Assistance to the Restructuring of the Economy (PHARE) programme (Robert, 2004).

Before analysing these converging external references I will briefly outline some contextual elements relative to the academic landscape in the region. Several analyses have shown that in Central and Eastern European countries, the academic systems have been affected by changes in this sector in a distinct way. In comparison with Western European countries, the challenges have been both similar and more impactful because of their speed and of local patterns. The massification of higher education took place largely in the 1990s while public funding allocated to the sector decreased (Slantcheva, 2003; Sigman, 2014). The concurrent HE privatisation process reached much higher proportions than in Western Europe with peak numbers registered in Poland and Romania: all in all, the private sector enrols around $27 \%$ of the student population in CEEC, while it averages $6 \%$ in Western Europe (Levy, 2012, p. 182). In the Polish case, the marketisation of the HE system that started in the beginning of the 1990s resulted in the development of a large private HE sector, whose expansion stopped in the second half of the 2000s. While about two thirds of Polish HEI are private, their number fell from 321 (out of 453) in 2012/2013 to 302 (out of 435) in 2014/2015 (GUS 2013, 2015). ${ }^{6}$

Table 1. Higher education institutions in Poland

\begin{tabular}{|c|c|c|c|c|c|c|c|}
\hline & $1995 / 96$ & $2000 / 01$ & $2005 / 06$ & $2010 / 11$ & $2011 / 12$ & $2012 / 13$ & $2014 / 15$ \\
\hline Public & 99 & 115 & 130 & 122 & 131 & 132 & 133 \\
\hline Private & 90 & 195 & 315 & 338 & 325 & 321 & 302 \\
\hline Total & $\mathbf{1 8 9}$ & $\mathbf{3 1 0}$ & $\mathbf{4 4 5}$ & $\mathbf{4 6 0}$ & $\mathbf{4 5 6}$ & $\mathbf{4 5 3}$ & $\mathbf{4 3 5}$ \\
\hline
\end{tabular}

Source : Polish Main Statistical Office (GUS), Polish Ministry of Higher Education and Research

The demographic explains the trend towards higher education 'deprivatisation' (Kwiek, 2016). While the overall number of students decreased from nearly 2 million in 2006 to 1,469 million in 2014 (GUS, 2015), this decline hit private HEI harder than the public ones. In Ukraine there were 525 public HEI institutions and 134 private ones in 2016, compared to 926 public and 111 private institutions two decades before (State Statistics 
Service of Ukraine, 2016). The decrease of the number of HEI is due not only to demographic reasons but also to the loss of the Crimean territory to Russia and the armed conflict in the eastern part of Ukraine. ${ }^{7}$ Both in Poland and in Ukraine, the statutory differences between private and public HEI do not explain the issue of fees, as many students enrolled in public tertiary education institutions still pay fees.

Table 2. Higher education institutions in Ukraine (level of accreditation I - IV)

\begin{tabular}{|c|c|c|c|c|c|c|c|c|}
\hline & $1995 / 96$ & $2005 / 06$ & $2010 / 11$ & $2011 / 12$ & $2012 / 13$ & $2013 / 14$ & $2014 / 15$ & $2015 / 16$ \\
\hline Public & 926 & 749 & 637 & 633 & 619 & 609 & 520 & 525 \\
\hline Private & 111 & 202 & 176 & 172 & 166 & 158 & 144 & 134 \\
\hline Total & $\mathbf{1 0 3 7}$ & $\mathbf{9 5 1}$ & $\mathbf{8 1 3}$ & $\mathbf{8 0 5}$ & $\mathbf{7 8 5}$ & $\mathbf{7 6 7}$ & $\mathbf{6 6 4}$ & $\mathbf{6 5 9}$ \\
\hline
\end{tabular}

Source : State Statistics Service of Ukraine $(2011,2016)$. http://ukrstat.gov.ua/

Notwithstanding their specificities, these domestic processes can hardly be disentangled from evolutions that take place in the Western world, as reformers at the national level have constantly referred to foreign academic models.

\section{The overarching European framework of reference}

As far as the CEECs are concerned, there is still a debate on how endogenous and exogenous dynamics combine in reform implementation. For some authors, European pressures have resulted in a growing convergence between their HE systems (Dobbins and Knill, 2009; Dobbins, 2011). Others persistently note 'no significant Europeanisation' of the HE system they analyse (Pabian, 2009). Varying levels of analysis and choices of data selection contribute to these contradictory results.

As far as the new EU member states (NMS) are concerned, three phases are generally identified after 1989 (Deca, 2015). The first was the decade of liberalisation and Westernisation, where exposure to foreign models could be expected. A second phase began with the EU accession negotiations, followed by the launch of the Bologna Process, suggesting openness to solutions developed at the European level. Finally, the third, post-accession phase is marked by further cooperation within the EHEA as well as the publication of international rankings and the increasing use of international 
comparisons. However, beyond this global scheme, the intensity of reforms and the relative influence of international organisations vary according to the domestic political context. Countries that were not part of the EU enlargement such as Ukraine were less dependent on the temporality of the accession process. Still, it makes sense to integrate former Commonwealth of Independent States (CIS) states into the analytical framework addressing their Europeanization and internationalization, especially in cases where their government's attitude towards the EU was influenced by internal political struggles.

EU programmes already played an overarching structuring role during the first phase of restoration of university autonomy in the early 1990s. The EU programme Tempus (Trans European Mobility Programme for University Studies) financed by PHARE funds helped in developing closer links and expanding knowledge transfers between universities from Eastern and Western Europe. ${ }^{8}$ Tempus triggered significant changes in the HE landscape as it helped restructure existing institutions, launch new curricula and study programmes, and promote cooperation with industry. In addition to providing structural support, Tempus encouraged socialisation and the dissemination of expert knowledge. It facilitated the emergence and consolidation of groups of HE experts who instigated reforms within their home universities and later contributed to the domestic dissemination of the Bologna Process. ${ }^{9}$ Extended to the former Soviet countries in 1993, the Tempus initiatives have strengthened transnational links between Eastern and Western scholars and academic managers. In Ukraine, the Tempus IV edition focused on the implementation of Bologna principles such as the three cycle system and curricula reforms connected to the labour market as well as 'Quality Assurance tools for the management of internationalization' (European Commission, 2012). This illustrates the difficulty of separating the Bologna Process itself and the EU educational initiatives, as they feed off each other.

In the EU candidate countries, European references became more visible in the context of EU accession. While some HE institutions implemented measures aimed at facilitating student mobility (such as the European Credit Transfer System or the twotier degree structure) on a bottom-up basis as early as in the 1990s, the perspective of accession provided an opportunity for more directive interpretations of the formally non-binding Bologna principles. The interviews with Polish experts show that the 
Bologna Process - and the international incentives as a whole - were not only considered as a non-negotiable package: these instruments were associated with

modernity and progress and considered as tools to transform society. ${ }^{10}$

The overarching belief that a country in transition cannot afford to opt out from the process was similar to the attitudes observed in other new EU Member States such as Romania (Deca, 2015). This domestic framing of the Bologna Process, which seems characteristic of the new democracies from Central and Eastern Europe, explains why the different provisions of the process have systematically been transformed into legal acts and detailed regulations.

\section{Looking for the impact of international organisations}

Before the growing focus on the EU level, countries from Central Europe had been exposed to the influence of international institutions active in the education sector. The interest of these organisations in the region did not start in 1989, as is shown, for instance, by UNESCO's 1972 initiative of opening a European Centre for Higher Education (CEPES) in Bucharest. Both UNESCO-CEPES and the World Bank have been actively involved in the transformations of the Romanian HE system after 1989 (Cîrstocea, 2014; Deca, 2015).

While international organisations active in the educational field have implemented several projects in Poland, their policy impact has been limited. These projects have led to the publication of several reports, which have fuelled public debate as a legitimate point of reference. However, these reports did not directly serve as a basis for reform. While international organisations called for the introduction of tuition fees for all students (World Bank, 2004; Canning \& al., 2007), this politically sensitive reform has never been explicitly implemented in Poland, where HE is constitutionally free. Yet, in practice, nearly half of all Polish students pay some kind of tuition fee.

The 2011 HE Act introduced compulsory fees for students who pursue a second major, but the Constitutional Court ruled against this practice in June 2014. This shows that domestic priorities and institutional legacies make it possible to bypass the recommendations of international organisations, which have repeatedly called for the diversification of HE revenues.

In Ukraine, non-European organisations such as the World Bank, USAID and the Soros 
Foundation have played an important role in HE reform assistance. ${ }^{11}$ Their resources and expertise have been welcomed by local policy-makers, even if domestic constraints provide the most direct explanation for the adopted reform frameworks. In Ukraine, where HE has suffered from underfunding, roughly half of the student body currently pay fees, including in public HEI. The strong budgetary pressure linked to the financial crisis and the cost of war in the Eastern part of the country have reinforced the trend of reducing the number of state-subsidised (i.e. free) 'contracts for the higher education training of specialists'. ${ }^{12}$ While this trend had already begun in 2010 - under the controversial minister of Education Dmytro Tabachnyk - the pro-European government that came to power in 2014 has further decreased the funding earmarked for these subsidised HE institutions. This decision, resulting from domestic material constraints, resonates well with the objective of 'diversify[ing] funding sources, drawing to a larger extent on private funding' included in the Commission's Modernization of higher education agenda (European Commission, 2011). However, it might conflict with the objective of increasing attainment levels in HE featured in the Europe 2020 strategy. This may also be detrimental to the so-called social dimension of HE, mentioned by the Bologna Process.

Another set of policy trends prioritised by international organisations has been reflected in various reforms that converged with Commission and OECD recommendations. They have introduced mechanisms enabling closer ties with the economic environment as well as quality assurance measures. Following these external recommendations, the Polish government invested in applied, market-oriented courses such as environmental protection (although the latter programme has recently struggled to attract enough students). In 2014 it introduced an ambitious data collection system to obtain information about the income of former students from the national social security office (which has triggered some concern about data protection). Despite this, much of HE organisation has remained unchanged, as no radical reform of university governance has been imposed upon the universities (Dobbins, 2015).

In Ukraine the very idea of state contracts for the training of specialists in strategic branches, which has its origins in the Soviet period, shows a correlation between the investments in HEI and the job market, with a central role still played by the state. A law that aimed at facilitating entry into the labour market for young holders of a HE 
degree was adopted in 2004 (European Commission, 2012). Several external assistance programmes have focused on the market relevance of HE curricula. The Strategy of Reforming Higher Education by 2020 identified a 'lack of mechanisms of interaction of high school with the labor market' and called for 'attracting professional public, employers to control HEIs and determine the content of learning' and for 'basing educational standards on professional standards' (Zhyliaev \& al, 2014). However, this strategy, which has been developed with the assistance of the United States Agency for International Development (USAID), has yet to be officially adopted by the government. ${ }^{13}$ These cases show that the decision to adapt to external policy recommendations may cause tensions between divergent policy objectives, side effects as well as a discrepancy between the declared policy direction and its implementation (particularly noticeable in the Ukrainian case).

In countries outside the EU the policy translation of international academic competition could lead to a greater stratification of the academic community. Policies aimed at diversifying HEI and the emergence of institutions targeting the label of "world-class university' are not so much a direct answer to the institutional recommendations of an IO, but rather a political recognition of the growing significance of global university rankings (Erkkilä, 2013). Even countries that seemed the most isolated from the international community such as Belarus, which was denied admission in the Bologna Process until 2015, have made several initiatives to attract foreign students (mainly from the former Soviet countries) (Gille-Belova, 2015). The Ukrainian government has also joined the trend and launched a policy aiming at differentiating its higher education institutions with the ambition to create national research universities but above all to tackle corruption, low quality of teaching and research problems (Oleksiyenko, 2014). Measures undertaken to promote the internationalization of the domestic HE system may thus illustrate a domestic effort to participate in the international academic exchange. 


\section{The political dimension of HE reforms. The Polish and Ukrainian cases}

Focusing on the domestic interpretations of the Bologna Process and of the EU recommendations on $\mathrm{HE}$ provides an opportunity to approach the Europeanization process through the prism of the political uses of European recommendations (Woll \& Jacquot, 2012). Furthermore, the Polish and the Ukrainian cases offer an opportunity to empirically refine the recent thesis on the (party) political dimension of Higher Education reforms. In this section I argue that it is important to take into account the configuration of each national political field to examine the extent to which existing cleavages influence the domestic framing of Western recommendations. The point is not to compare the structure of both party systems as such, as they diverge and result from different historical evolutions. In Poland, the left-wing parties have been marginalised over the past decade even if their leaders tried to distance themselves from their authoritarian and Communist roots. Since 2005, the national-conservative Law and Justice (PiS) and the liberal Civic Platform (PO) have dominated the party landscape. In Ukraine, there is a strong geographical and linguistic component - which accounts for the greater presence of the pro-Russian Party of the Regions in the Eastern part of the country - but also a strong personalisation of political parties (an example being the Bloc Petro Poroshenko). According to some authors, it is difficult to speak of a functioning party system in Ukraine, as most parties are weakly institutionalised and many of them appear as channels 'for converting economic capital into political capital' (Wilson \& Birch, 2007: 53). Following the Maïdan Revolution, the Russian annexation of Crimea in 2014 and the military conflict in the Eastern part of the country, the cleavage between pro-European and pro-Russian forces has come to the fore.

The Bologna Process has been a challenge to the approach which considers the politics dimension as an important explanatory variable of change: in many countries, the tendency to harmonise HE systems seems to be shared regardless of the political majority in office. In the French and Polish cases for instance, over the past fifteen years noticeable changes in the policy interpretation of the Bologna Process have been mainly rhetorical, with centre-left wing majorities stressing the importance of public funding for $\mathrm{HE}$ and the social dimension and centre-right governments emphasising the 
competitive allocation of public funds. However, a closer look should be taken to see whether the party political dimension can be an explanatory variable that helps understanding differences in policy interpretation and outcomes. Recent studies have reevaluated this dimension - albeit focusing exclusively on Western European countries and privileged a Left/Right divide as the main variable (Jungblut, 2014; 2015). This cleavage does not necessarily apply to CEEC, where other dividing lines can intervene, such as the divide between the socio-economic liberal and illiberal parties (as in the Polish case) or between a pro-EU and pro-Russia majority (as in Ukraine). Therefore it is worth asking whether and to what extent a government's attitude towards European integration and the country's relationship towards the EU can be an indication of its stance toward the Bologna Process and HE reforms in general.

\section{Europe as a window of opportunity for Ukrainian reformers}

After the beginning of the conflict in the East and the Russian annexation of Crimea, the new Ukrainian government launched an ambitious higher education reform. The Law on Higher Education adopted in 2014 is based on three projects that had been discussed since 2008. It was only after a pro-European government came to power in February 2014 that a window of opportunity opened for this ambitious reform led by the Minister of Education and Science, the former rector of Kyiv Mohyla Academy, Serhiy Kvit, and his colleagues (Kvit was replaced, in April 2016, by Lilia Grinevich, from the same proEuropean majority). Since Ukraine joined the Bologna Process in 2005, this is the first comprehensive attempt to align the domestic HE on the European Higher Education Area's functioning mechanisms. The last comprehensive Law on Higher Education dates back to 2002. In 2011, a National Qualifications Framework was approved by the Council of Ministers of Ukraine. ${ }^{14}$ The 2014 law announced priority treatment for 'National higher education institutions' (art. 29) and 'Research Universities' (art. 30), which are entitled to extra budgetary support. In tune with the objective of quality and relevance of higher education included in the EU's HE modernisation agenda, the Ukrainian government has planned to reduce the number of HEI. ${ }^{15}$ For this purpose, hundreds of technical schools and colleges were supposed to be re-labelled as vocational education institutions (a reform that former governments had already unsuccessfully tried to carry out). This met with widespread opposition from technical 
HEI. ${ }^{16}$ The idea of reducing the number of universities through 'mergers, consolidation, clustering and specialisation' reflects the priorities of the European Commission, formulated in the Education and Training 2020 strategy. ${ }^{17}$

In Ukraine, internationalisation appears as an important criterion to claim the status of 'Research university', as the latter considers the HEI's 'level of integration in the global education and research space', the 'place in the national, industry and/or international rankings' as well as the 'number of publications by indexes of recognized international scientometric databases and international peer reviewed journals' (Law on Ukraine Higher Education, 2014, p. 35). However the implementation of these provisions remains unclear, not only because few Ukrainian scholars are active in international publication channels but also due to the dire budgetary situation of the Ukrainian state. As the available funds are prioritised for the conflict that is tearing the Eastern territories apart, the educational sector is struggling to maintain its level of funding. ${ }^{18}$ As far as the Bologna Process is concerned, the Ukrainian 2014 HE Law refers to the European Higher Education Area with provisions on the ECTS, learning outcomes, a National Quality Assurance Agency for Higher Education, 'alignment of the National Qualifications Framework with the Qualifications Framework of the European Higher Education Area' (art. 74). However, several structural problems hamper the implementation of these provisions. The problem of corruption persists even though the government intends to address it by setting up more transparent mechanisms of student and staff recruitment. On the domestic level, the principle of an independent quality assurance agency is new. Yet this agency could not launch its activities by the time of the legal deadline because elected members did not meet the required anti-corruption standards. ${ }^{19}$ This shows that the pro-European orientation of the central government is not a sufficient prerequisite for the successful implementation of the designed reforms as more path-dependent institutional coalitions may postpone or block the new measures. The entry into force of the EU-Ukraine Association Agreement and Ukraine's inclusion in the Horizon 2020 research and innovation funding programme open new perspectives for cooperation. Much will however depend on the country's political situation and the evolution of the conflict with Russia. 
Bringing the domestic dimension of the HE reforms back in: the Polish case

In Poland, which was signatory to the Bologna Declaration in 1999, both moderate left and right-wing governments supported the principles of the Bologna Process and took several policy steps in that direction. The 2005 Higher Education Act translated the proposals of the Bologna ministerial meetings into a legal framework. However, this reform was deemed insufficient by the liberal government led by Donald Tusk, the leader of the Civic Platform (PO) that came to power in 2007. The new HE Minister, Barbara Kudrycka, launched a comprehensive reform of the academic system. In 2010, the government adopted a series of legal acts reforming the research system followed by a Higher Education Act, which entered into force in October $2011 .^{20}$ This new law introduced evaluation and competition mechanisms, which opened the race to the title of best faculty, 'national research leading centre' (KNOW) 'diamond grant' and other measures promoting the internationalization of academic publications and diversification of research centres. The vocabulary of competition has prevailed in the announcements of these measures, in tune with the narratives diffused by international organisations active in the field.

The HE Law of 2011 and the related regulations led to the definition of syllabi in terms of learning outcomes, the publication of a National Qualification Framework and numerous initiatives promoting HE quality enhancing mechanisms as well as student and academic staff mobility. In June 2015, the Polish Ministry of Science and Higher Education adopted a Programme of HE internationalisation which systematised measures aimed at attracting foreign students and researchers to the country and at facilitating mobility for domestic scholars, for the purposes of boosting the country's competitiveness on the European and global market. ${ }^{21}$ The available EU structural funds were to support these efforts (Ministry of Science and Higher Education, 2015).

However, although it is considered as a committed member of the Bologna Process, Poland's position in the European Higher Education Area has raised some international concern after the October 2015 parliamentary elections won by the nationalconservative party Law and Justice (PiS). In the weeks following the electoral victory, leading PiS representatives publicly expressed their scepticism towards the Bologna Process (Flis, 2015). Yet, the new minister of Science and Higher Education Jarosław 
Gowin, appointed in November 2015, has not announced any radical departures from the previous government's policy orientations and measures that triggered competition among universities and researchers. Overall, in the Polish case, changes in orientation of the ruling majority (Left / Right, conservative / liberal) have so far triggered mainly rhetorical policy changes. Although it is too early to make any definitive statements about further policy change, both the Polish and Ukrainian cases show that EHEA membership does not necessarily imply a linear advancement towards the common goals.

\section{Conclusion}

This contribution confirms the importance of external incentives for HE reform in the context of post-communist transformation and EU accession. However, it shows that these external factors do not exercise influence per se. They depend on domestic priorities and narratives and can take different forms. In CEEC, it is difficult to disentangle the impact of European and other international factors, both IO recommendations and transnational processes such as the rise of global rankings. Their respective influences may be observed through the ways in which domestic policymakers and experts interpret external recommendations. In the Polish case, recommendations made by the European Commission and during Bologna ministerial conferences have played a major role. They have been useful to policy-makers and experts, who have used existing reports as legitimising references to show that their reform projects are merely a local version of more global rules.

Contrary to some older EU member states, which may have more leeway in adjusting the various features of the Bologna Process to the domestic educational system, Polish policy-makers have tried to bend their educational system to comply rather strictly with external recommendations. Several new EU Member States such as Poland and Romania were eager to present themselves as 'good pupils' in European arenas. While EU compatibility and modernisation used to be authoritative arguments to silence academic dissent in the accession period, the growth of EU-critical political movements in the region shows that the argument of an external constraint is no longer sufficient. It appears more audible in the EU neighbourhood, as in the case of Ukraine, in the 
aftermath of the Euromaidan movement. As the country's new governing elites owe their legitimacy to their promises of implementing the EU-Ukraine Association Agreement and fighting corruption, the pro-European Ukrainian government has a window of opportunity to implement an ambitious HE reform. However, whether the window remains open depends heavily on the overall economic and geopolitical situation and is therefore uncertain. Whether Ukrainian experts and policy-makers are willing and capable of convincing larger parts of the academic community of the usefulness of the Bologna Process, which is remote from their direct, material problems, also remains to be seen. All in all, in CEEC the domestic retranslation of policy patterns and the government's attitude towards European integration have to be taken into account in order to better understand shifts and stagnation periods in HE policy reforms. 


\section{References}

Altbach P. G. (2003) Introduction to Higher Education theme issue on the Academic Profession in Central and Eastern Europe. Higher Education, 45(4): 389-389.

Altbach P. G. (2007), Tradition and Transition. The International Imperative in Higher Education. Rotterdam: Sense Publishers.

Batory A. \& Lindstrom N. (2011) The Power of the Purse: Supranational Entrepreneurship, Financial Incentives and European Higher Education Policy. Governance 24(2): 311-329.

Börzel, T. A., \& Risse, T. (2000). When Europe Hits Home: Europeanization and Domestic Change. European Integration online Papers, 4(15).

Bruno I., Clément P. \& Laval C. (2010) La grande mutation. Néolibéralisme et éducation en Europe. Paris: Syllepse.

Canning M., Godfrey M. \& Holzer-Zelazewska D. (2007) Higher education financing in the new EU member states : leveling the playing field. World Bank working paper ; no.112. Washington, DC: World Bank.

Cîrstocea I. (2014) Les restructurations de l'enseignement supérieur en Roumanie après 1990 : apprentissage international de la gestion, professionnalisation de l'expertise et politisation de l'enjeu universitaire. Revue d'études comparatives Est-Ouest, 45 (1) : $125-163$

Cîrstocea I, Dakowska D and Sigman C (2014) Avant-propos. Introduction to the special issue Les transformations des espaces académiques centre-est-européens depuis 1989. Revue d'études comparatives Est-Ouest, 45 (1): 125-163.

Croché S. (2010) Le pilotage du processus de Bologne. Brussels: Bruylant.

Dakowska D. (2015) Between Competition Imperative and Europeanisation. The Case of Higher Education Reform in Poland. Higher Education, 69 (1): 129-141.

Dakowska D. \& Harmsen R. (2015) Laboratories of Reform? The Europeanization and Internationalization of Higher Education in Central and Eastern Europe. European Journal of Higher Education 5 (1): 4-17.

Dale R. (1999) Specifying globalisation effects on national policy: a focus on the mechanisms, Journal of Education Policy, 14 (1): 1-17.

Dale R. \& Robertson S., (2009) Globalisation and Europeanisation in Education. Oxford, Symposium Books.

Deca L., (2015) International Norms in the Reform of Romanian Higher Education: A Discursive Analysis. European Journal of Higher Education, 5 (1): 34-48. 
Dobbins, M. (2011) Higher Education Policies in Central and Eastern Europe: Convergence towards a Common Model?. Houndmills, Basingstoke: Palgrave Macmillan.

Dobbins, M. \& Khachatryan S. (2014) Europeanization in the "Wild East"? Analyzing higher education governance reform in Georgia and Armenia. Higher Education 69 (2): 189-207.

Dobbins M and Knill C (2009) Higher education policies in Central and Eastern Europe: convergence towards a common model?. Governance, 22(3) :397-430.

Dobbins, M., (2015) Exploring the governance of Polish public higher education: balancing restored historical legacies with Europeanization and market pressures. European Journal of Higher Education, 5 (1): 18-33.

Dolowitz D. P., Marsh D., (2000), Learning from Abroad: The Role of Policy Transfer in Contemporary Policy Making, Governance, 13(1): 5-24.

Erkkilä T. (dir.), (2013), Global University Rankings: Challenges for European Higher Education. Houndmills, Basingstoke: Palgrave Macmillan.

European Commission (2011) Communication from the Commission to the European Parliament, the Council, the European Economic and Social Committee and the Committee of Regions. Supporting growth and jobs - an agenda for the modernisation of Europe's higher education systems, COM/2011/0567 final.

European Commission (2012) Education, Audiovisual and Culture Executive Agency (EACEA), Tempus, Higher Education in Ukraine, July 2012.

Flis D. (2010) 5-2 zamiast 3+2. Posłowie PiS zapowiadają zmiany ważne dla studentów (5-2 instead of $3+2$. PiS MEPs announce important changes for students). Gazeta wyborcza, 4th November 2015, http://wyborcza.pl/1,75398,19134142,5-2-zamiast-3-2poslowie-pis-zapowiadaja-zmiany-wazne-dla.html accessed on $15^{\text {th }}$ December 2016.

Garcia S. (2007) L'Europe du savoir contre l'Europe des banques ? La construction de l'espace européen de l'enseignement supérieur. Actes de la recherche en sciences sociales, 166-167 (1-2) : 80-93.

Georgakakis D. (Ed.) (2012), Le champ de l'Eurocratie. Une sociologie politique du personnel de l'UE, Economica.

Gille-Belova O. (2015) Beyond the limits of the European Higher Education Area: the case of Belarus. European Journal of Higher Education 5 (1) : 83-95.

Guiraudon V., Favell A., (Eds.) (2011), Sociology of the European Union, Palgrave Mac Millan. 
GUS / Central Statistical Office (2015) Higher Education Institutions and their Finances in 2014, [Statistical Information and Elaborations], Warsaw, 2015, available at http://stat.gov.pl/en/topics/education/ (consulted on $15^{\text {th }}$ October 2016).

GUS / Central Statistical Office (2013) Higher Education Institutions and their Finances in 2012, [Statistical Information and Elaborations], Warsaw, 2013, available at http://stat.gov.pl/en/topics/education/education/higher-education-institutions-andtheir-finances-in-2012,2,5.html (consulted on $15^{\text {th }}$ October 2016).

Huisman, J.; Adelman, C.; Hsieh, C-C, Shams, F. \& Wilkins, S. (2012), Europe's Bologna Process and Its Impact on Global Higher Education, in: D. K. Deardorff, H. de Wit, J. D. Heyl, T. Adams, The SAGE Handbook of International Higher Education, Sage.

Jorge de Melo, S. (2013), 'Regionalising higher education transformation in Europe: what kind of positionality for the Council of Europe in relation to the Bologna Process, 1999-2010', Ph.D. thesis, University of Bristol, 142-168.

Jungblut, J. (2014) Partisan Politics in Higher Education Policy: How Does the LeftRight Divide of Political Parties Matter in Higher Education Policy in Western Europe? in : Gaële Goastellec \& France Picard (Ed.), Higher Education in Societies - A Multi Scale Perspective. Sense Publishers, Chapter 6, pp. 87-112.

Jungblut, J. (2015) Bringing political parties into the picture: a two-dimensional analytical framework for higher education policy, Higher Education, 69 (5): 867-882.

Keeling R. (2006) The Bologna Process and the Lisbon Research Agenda: The European Commission's Expanding Role in Higher Education Discourse, European Journal of Education 41(2): 203-223.

Knight J. (2003) Updated Internationalization definition. International Higher Education, 33: 2-3.

Knight J. (2011) Internationalization: Concepts, Complexities and Challenges, in: James J. F. Forest and Philip Altbach (Eds.), International Handbook of Higher Education. Part 1. Dordrecht, Springer, pp. 207-227.

Kwiek M. (2016) Chapter 16, 'From Privatization (of the Expansion Era) to De privatization (of the Contraction Era): A National Counter-Trend in a Global Context', in : S. Slaughter \& B. J. Taylor (Eds.), Higher Education, Stratification and Workforce Development, Dordrecht, Springer International Publishing Switzerland, Higher Education Dynamics, 45 : 311-329.

Law on Ukraine Higher Education (2014), July $1^{\text {st }}$, $\mathrm{n}^{\circ}$ 1556-VII, available at http://zakon5.rada.gov.ua/laws/main/en/annot, accessed on the 5th January 2017 
Leuze K., Martens K. \& Rusconi A. (2007) New Arenas of Educational Governance the Impact of International Organizations and Markets on Education Policy Making, in: K. Martens, \& al., New Arenas of Education Governance. The Impact of Internatinal Organizations and Markets on Education Policy Making, Houndmills, Basingstoke, Palgrave Macmillan, pp. 3-15.

Levy, D. C. (2012). How Important Is Private Higher Education in Europe? A Regional Analysis in Global Context. European Journal of Education, 47 (2): 178-197.

Lingard B. (2006) Globalisation, the research imagination and deparochialising the study of education. Globalisation, Societies and Education 4 (2): 287-302.

Martens K. \& Wolf K. D. (2009) 'Boomerangs and Trojan Horses: the Unintended Consequences of Internationalizing Education Policy through the EU and the OECD' in A. Amaral, G. Neave, C. Musselin, P. Maassen (dir.), European Integration and the Governance of Higher Education and Research, Dordrecht, Springer: 81-107.

Martens K. \& Jakobi, A.-P. (Eds.) (2010) Mechanisms of OECD Governance International Incentives for National Policy Making. Oxford: Oxford University Press.

Ministry of Science and Higher Education (2015), Program umiędzynarodowienia szkolnictwa wyższego (Programme of HE internationalization), Warsaw, http://www.nauka.gov.pl/aktualnosci-ministerstwo/program-umiedzynarodowieniaszkolnictwa-wyzszego.html (accessed on 15th October 2016).

Muller P., Ravinet P. (2008) Construire l'Europe en résistant à l'UE ? Le cas du processus de Bologne. Revue Internationale de Politique Comparée, 15(4) : 653-665.

Mundy K. (2007) Education Multilateralism - Origins and Indications for Global Governance in: Kerstin Marten, Alessandra Rusconi and Karen Leuze, New Arenas of Education Governance. The Impact of International Organizations and Markets on Education Policy Making, Palgrave Macmillan, pp. 19-39.

Normand R. (2010) 'Expertise, Networks and Indicators: the construction of the European strategy in education', European Educational Research Journal, 9(3) : 407421.

Oleksiyenko A. (2014) Socio-economic forces and the rise of the world-class research university in the post-Soviet higher education space: the case of Ukraine, European Journal of Higher Education, 4(3) : 249-265.

Pabian, P. (2009) Europeanisation of Higher Education Governance in the PostCommunist Context: The Case of the Czech Republic', In A. Amaral, G. Neave, C. Musselin, and P. Maassen, (Eds). European Integration and the Governance of Higher Education and Research, Dordrecht: Springer, pp. 256-278.

Rizvi F., Lingard B. (2009) Globalizing education policy. Routledge. 
Robert C. (2004) Doing politics and pretending not to. The Commission's role in distributing aid to Eastern Europe, in A. Smith (Ed.), Politics and the European Commission. Actors, interdependence, legitimacy, Routledge/ECPR Studies in Political Science, pp. 17-29.

Rowell J. \& M. Mangenot (Eds.) (2011), A political sociology of the European Union. Reassessing constructivism, Manchester University Press.

Serrano-Velarde, K. (2015), Words into Deeds: The Use of Framing Strategy in EU Higher Education Policy, Critical Policy Studies, 9 (1): 41-57.

Sigman, C. (2014) Les transformations de l'enseignement supérieur en Russie: évolution du secteur public et stratégies d'établissements. Revue d'études comparatives Est-Ouest 45 (1): 21-54.

Slantcheva S. (2003) The Bulgarian Academic Profession in Transition. Higher Education, 45(4) : 425-454.

State Statistics Service of Ukraine (2016) Основні показники діяльності вищих навчальних закладів Украӥни на початок 2015/16 навчального року. Статистичний бюлетень, Kiev.

Walkenhorst H. (2008) Explaining change in EU education policy. Journal of European Public Policy 15 (4): 567-587.

Wilson \& Birch (2007), 'Political Parties in Ukraine. Virtual and Representational' in: P. Webb, S. White, Party Politics in New Democracies. Oxford, New York: Oxford University Press: 53-83.

Woll C. \& Jacquot S. (2010) Using Europe: Strategic Action in Multi-Level Politics. Comparative European Politics, 8 (1): 110-142.

World Bank (2004) Tertiary Education in Poland. Warsaw.

Vukasovic, M. (2012), European Integration in Higher Education in the Western Balkan Countries. A review of literature, Working Paper, $\mathrm{n}^{\circ}$ 1, EIHER-WBC Working Paper Series $\quad$ http://www.herdata.org/research/eiher-wbc-working-paper-series/2012/60 (accessed on 15th October 2015).

Vukasovic, M. (2015) Concluding comments: when international, European and domestic influences collide. European Journal of Higher Education, 5(1): 96-106.

Zgaga P., Teichler U. \& Brennan J. (Eds.) (2013) The Globalisation Challenge for Higher Education: Convergence and Diversity, Centres and Peripheries. Higher Education Research and Policy (4), Peter Lang.

Zhyliaev V., Kalashnikova S., Kovtunets V. \& al., (2014) Strategy of Reforming Higher Education by 2020 (translated from Ukrainian). 


\author{
Dorota Dakowska \\ Professor of Political Science \\ University Lumière Lyon 2 \\ ENS Triangle (UMR 5206) \\ Institut Universitaire de France \\ dorota.dakowska@univ-lyon2.fr
}

\footnotetext{
${ }^{1}$ This analysis is based on different types of documents related to the reforms (legal acts, published and unpublished reports, communications, press articles) as well as on 60 semi-structured interviews with educational experts, representatives of the academic community and higher civil servants at national, European and international level (European Commission, Council of Europe, OECD, UNESCO) in Poland, France and Ukraine, which I have conducted in 2010-2015. The interviews were conducted either in English, French, German, Polish or Russian and lasted over an hour on average. Consultation of the Council of Europe archives complemented the empirical part of the research. This research has been funded by a Junior Fellowship of the Institut Universitaire de France.

${ }^{2}$ The respective contributions of these organisations differ according to the time period and context. UNESCO has the most long-standing tradition of educational assistance but it has recently lost some ground against other organisations. In the 1990s, the Council of Europe coordinated a Legislative Reform Programme in CEEC, focused on higher education, which did not have the same impact in all countries. The OECD and the World Bank issued periodical evaluations of the countries' tertiary education sector. Rather than evaluating the respective impact of these organisations' strategies, the focus on the domestic uses of their recommendations helps appreciating their dynamic and contingent character.

${ }^{3}$ Archives of the Council of Europe, G4 1129, Direction générale IV -- Direction de l'éducation scolaire, extrascolaire et de l'enseignement supérieur, Bologna Process, Bergen summit, May 2005, Memorandum, Strasbourg May 24, Note for the attention of G. Battaini Dragoni, Mission report, Ministerial conference of the Bologna Process and BFUG, Bergen, May, 18-20 2005.

4 This view is widely shared by Polish policy-makers and pro-reformist experts [interviews $1,3,5]$ as well as by current Ukrainian HE policy makers [interviews 70, 71, 73].

${ }^{5}$ Interview no. 76, DAAD, 12 April 2016; Interview no. 78, HRK, 13 April 2016.

${ }^{6}$ While there was one non-public university at the end of the communist period, the number of non-public HEI reached 18 in 1992-93, 90 in 1995-96, 195 in 2000-2001, 326 in 2008-2009 and 338 in 2010-2011. Ministry of Science and Higher Education, Statistical data on HE. In 2014, 24.4\% of all students studied in a private HEI (GUS, 2015, p. 30).

${ }^{7}$ Since 2014, the State Statistics Service of Ukraine has excluded the 'temporarily occupied territories of the Autonomous Republic of Crimea, the city of Sevastopol and part of the anti-terrorist operation zone' from its data. State Statistics Service of Ukraine, Demographic and Social Statistics/Education, http://ukrstat.gov.ua/, accessed on $7^{\text {th }}$ October 2016.

${ }^{8}$ Adopted by the Council on 7 th May 1990, Tempus was extended to the former Soviet republics financed by the Technical Assistance to the Commonwealth of Independent States (TACIS) programme in 1993. It was closed in 2000 for the countries associated with the EU but extended to other exYugoslavia and neighbourhood countries.

${ }^{9}$ Interviews with Polish Bologna experts [nos. 5, 13, 21, 28].

${ }^{10}$ Interviews with policy-makers at the Polish Ministry of Science and Higher Education [no. 1] and the Parliament [no. 6].

${ }^{11}$ Interviews in the Ukrainian Ministry of Education [no. 73], Parliament [nos. 70 and 71] and with a Ukrainian HE expert [no. 66].

12 Law of Ukraine on Higher Education, 2014, esp. Art. 72 'Preparation and placement of state contracts'.

${ }^{13}$ The document was scheduled to be discussed by the National Reforms Council in 2016. National

Reforms Council, Implementing reforms, Education reform

http://reforms.in.ua/en/reform/indicator/11083 (consulted on 7th January 2016).

${ }^{14}$ In January 2016, procedures concerning self-certification (verification) compatibility with European Qualifications Frameworks were being prepared. National Reforms Council, Implementing reforms, Education reform http://reforms.in.ua/en/reform/indicator/11088 (consulted on 15th June 2016).
} 
${ }^{15}$ Interviews at the Ukrainian Verkhovna Rada (Parliament) [nos. 70 and 71].

${ }^{16}$ According to HE statistics, there were 803 HEI in 2013-2014 (with 2,052 million students), including 167 private ones, and 299 universities. The situation is out of the Ukrainian government's control in Crimea but also in Donbass, where 215000 students were registered. Some of them moved to other parts of the country; others stayed in the separatist territories. Lilia Hrynevych, Verkhovna Rada, Higher Education in Ukraine; interviews in Kyiv, October 2015.

${ }^{17}$ European Commission, Directorate-General for Education and Culture, ET 2020 working group, mandate, WG on Modernisation of Higher Education, January 2014 - October 2015.

${ }^{18}$ Interviews at the Verkhovna Rada (Parliament) [nos. 70 and 71] and in the Ministry of Education [no. 73], 27-28 October 2015.

19 'Elections were held, but the Agency was composed of former officials who have come under the law of cleansing power'. In April 2016, no director had been appointed and the Agency was not functioning. National Reforms Council, Implementing reforms, Education reform http://reforms.in.ua/en/reform/indicator/11090 (consulted on 15th June 2016).

${ }^{20}$ The legal package of six Acts reforming Polish Science has been adopted by the Parliament, published on 4 June 2010 and entered into force on 1 October 2010. The HE Act has been revised several times until 2014.

${ }^{21}$ Interviews at the Polish Ministry of Science and Higher Education [no. 1, 20 July 2010; no. 43, 30 July 2014]. 